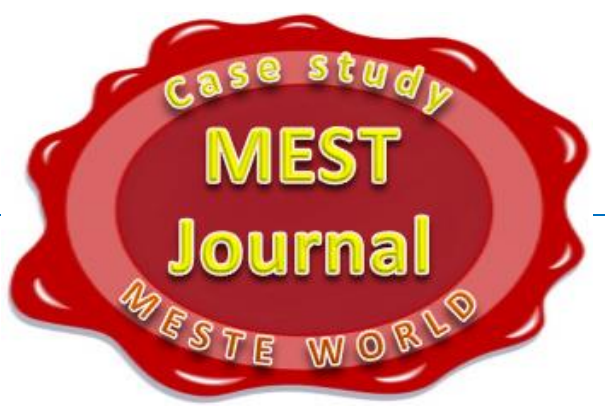

\title{
STATUS AND PRACTICES FOR MANAGING CONSTRUCTION WASTE IN THE REPUBLIC OF BULGARIA
}

\author{
Konstantin Tasov \\ Higher Shool of Civil Engeneering (VSU) "Lyuben Karavelov", Sofia, Bulgaria \\ Ventsislav Stoyanov \\ Higher Shool of Civil Engeneering (VSU) "Lyuben Karavelov", Sofia, Bulgaria \\ (C) MESTE \\ JEL Category: Q53
}

\begin{abstract}
This report discusses the need for construction and demolition waste management aimed at preserving the environment. It points out the need for waste management in the country based on practices adopted in the European Union. The report makes an analysis of the current state of construction and demolition waste management in the Republic of Bulgaria. It points out the existing practices of collection and transportation of construction and demolition waste. It also points out practices with negative effect on these processes. The report identifies specific characteristics of construction and demolition waste management. Along with solutions to problems with environmental protection, the report underscores the need for understanding and application of the social and economic opportunities that underlie effective construction and demolition waste management. The report outlines the major directions for work and the practical actions needed for recycling the construction waste. The report shows the main sources of waste creation from construction and demolition in the Republic of Bulgaria in the upcoming years until 2020. The report lays out in brief the factors that influence and will influence the volume and characteristics of construction and demolition waste. The report identifies the positive changes and effects that should occur as a result of the developed and implemented Strategic Plan for Management of Construction and Demolition Waste in the Republic of Bulgaria for 2011-2020. It points out the expected probable amounts for the different types of construction and demolition waste by 2020. The report identifies the goals of the adopted Ordinance for Management of Construction Waste and Application of Recycled Construction Materials. Favorable legal and economic conditions for the deployment of new technologies for construction waste recycling and recovery are expected as a result of achieving these goals in accordance with the financial situation of the companies and the state. The report draws the conclusion that the implementation of the Strategy and the requirements of the Ordinance will help reduce the negative impact on the environment and stimulate investment in waste management.
\end{abstract}

Address of the author:

Konstantin Tasov

莑=ttasov_konstantin@abv.bg 
Keywords: management of natural resources and waste, construction and demolition waste, landfilling, recycling, reclaiming, sustainable development

\section{INTRODUCTION}

Sustainable management of natural resources and waste takes an extremely important place in environment preservation and is at the core of harmonious socioeconomic development of society.

In the past 30 years, waste was at the basis of European Union environmental policy. In terms of waste management, significant progress has been made. Over time waste began to be seen as a valuable resource for the industry. Reuse, recycling and reclaiming of energy from waste is applied to reduce its quantity. Despite the progress made, waste continues to be a problem. Moreover, an increase in the quantities of generated waste is reported. The potential for reuse, recycling and reclaiming of waste is not yet fully exploited. New knowledge about the environmental impact of these resources should be fully reflected in policy on waste management.

\section{MANAGING CONSTRUCTION WASTE IN BULGARIA}

Waste management, including construction waste, both in the European Union and the Republic of Bulgaria is based on a hierarchy of priorities set out in the legal framework. The first priority is the prevention of the generation of construction waste, followed by reclaiming and recycling of waste, and last but not least - ways of waste disposal. It is necessary to follow this hierarchy while at the same time in each specific case the best solution should be sought with regards to environment protection.

On top of this, consideration should be given to the social aspects and economic capabilities. Construction and demolition waste in most cases have good characteristics and the recycled materials from construction and demolition waste is with a comparable quality to that of natural resources.

Construction and demolition waste management actions that have been adopted internationally and within the European Union are regulated by the legal framework. This framework overall consists of:

- Directive 2006/12/EC on waste;

- Decision of the European Commission (COM 2000/532/EC) establishing a list of wastes

- Directive 1999/31/EC on the landfill of waste;

- Council Decision establishing criteria and procedures for the acceptance of waste at landfills (2003/33/EC);

- Directive (89/106/EEC) on construction products.

In accordance with the legal framework and the requirements set in it, the practical activities in the processing of construction waste should be aimed to:

- Development of specific regulations for the management of construction waste based on hierarchical principles, the responsibilities of the producer of this waste and improvement of administrative functions;

- Binding between the issuance of a construction permit and requirements for the separation of waste at the place of their formation, in order to facilitate further management;

- Stimulation of controlled demolition procedures as a prerequisite for obtaining recyclable materials with quality indicators relevant to their new application;

- Development of economic and financial criteria, promoting the use of recycled materials instead of natural resources;

- Use of recycled construction waste with a suitable fractional composition for technical rehabilitation of threatened areas;

- Solving environmental aspects of recycling and the use of construction waste for safeguarding the ecological balance between man and nature;

- Giving absolute priority to recycling and creating conditions for that - reducing the disposal of construction waste within the possibilities of the specific stage, which above all means implementing widespread separate waste collection; 
- Introduction of standards (according to European requirements) that are applicable to both ordinary materials and those derived from construction and demolition waste recycling. For example, the current standard for aggregates for concrete does not include recycled aggregates, as it is based on old Bulgarian state standards;

- Suspension of the harmful practice for hazardous construction and demolition waste, due to limited number of landfills for hazardous construction and demolition waste, to be deposited in existing landfills for household waste. Furthermore, this practice destroys components of construction and demolition waste that can be reclaimed.

- Implementation of a system (scheme) for tracking of waste by composition and quantities from the moment of their formation until their reclaiming or disposal, if they contain hazardous construction and demolition waste. This is especially important in the forced demolition of illegal (and for other reasons) construction sites.

- Elimination of the illegal transportation of construction waste, which is a problem among more developed European countries as well.

- Choice of methods and technologies for the recycling of construction and demolition waste as a function of their economic, technical, technological, organizational, social and environmental viability. In our opinion, waste treatment methods are also due for serious rethinking (and ranking). As an example, waste incineration main problem arises from the incompatibility of the presently known incineration facilities with modern requirements. They are definitely not compatible with other types of waste treatment - not coincidentally, waste incineration is now considered an obsolescent technology in developed countries;

- Provision by the state of conditions for producing and selling recycled materials from construction and demolition waste, at an affordable price and satisfactory quality;

- While in the design of buildings and facilities to take measures to reduce waste in the subsequent destruction and allow reuse;
- Setting of specific requirements for producers to discontinue the use of harmful substances in the materials and products for construction (such as asbestos, other flame retardants, heavy metals, etc.). As an example, bituminous waterproofing of concrete reduces the degree of recyclability subsequently;

- Guarantee a no-compromise enforcement of the legal requirements for construction and demolition waste management and a systematic harmonization with the European requirements for environmentally sound management of natural resources and waste.

EU policy on waste management is based on the concept of hierarchy in waste management. This means to focus primarily on:

- Prevention based on the possibilities at waste creation;

- Recycling and reuse where prevention is not possible;

- Landfilling as a last resort, as this is considered in the Concept of the EU to be the most unfavorable way of waste treatment.

Despite the fact that European legislation on waste is continuously improving, some problems of the legal framework still remain. Directive 2006/12/EC, for example, contains the definitions "recovery" and "disposal" of waste and methods of their utilization by:

- Extraction of raw materials and energy from waste;

- The methods of final disposal of waste by incineration or land-filling.

The current state, however, shows what happens as a result of land-filling, as well as in subsequent waste treatment. In our opinion, methods of waste treatment are also subject to serious rethinking (and ranking). As an example, during waste incineration the main problem arises from the incompatibility of the presently known incineration facilities with modern requirements. They are definitely not compatible with other types of waste treatment either; not accidentally, incineration in developed countries is now considered a dying technology. The still unsatisfactory state of separate waste collection and separate treatment is added on top of these issues with both landfilling and incineration. 
Management of waste from construction, repair and maintenance of buildings currently in Republic of Bulgaria is performed under local regulations for waste management. Almost all of the construction and demolition waste is deposited at landfills still exist in many municipalities sites, provisionally called "construction waste landfills".

Existing practices in collection and transportation of waste from households in the municipalities are very different. In the majority of municipalities (so far) population who performs repairs paid for the services, transportation and disposal of construction and demolition waste companies that perform this service. In many communities this is done by so called Local Domestic Municipal Services. There is also a practice known small quantities of waste from maintenance and repair of buildings to be disposed of in household waste containers, and larger amounts to be placed in containers, as subsequently transported by the companies carrying out the collection of household waste. These practices can not be considered good. They should definitely be suspended after the construction and operation of regional landfills by close all illegal landfills for municipal and construction waste.

Waste that occur on sites undergoing construction and demolition or reconstruction of buildings containing insulation, gypsum, foil wrapping, small amounts of concrete, broken bricks and tiles, waterproofing materials, wood waste residues plaster and plaster and other landfilled or used for backfilling .

Demolition is an activity in which considerable amounts of waste, most of which have a high potential for recycling. Currently in Republic of Bulgaria are more than 50 companies engaged in demolition. Activities of these companies is regulated by Law on Spatial Planning. Companies engaged in these activities are provided with modern equipment for demolition of concrete and brick buildings and facilities, including the organization and use of processes Demolition, Salvage and disposal of construction waste. In some cases demolition sorting in place of bricks, metal and wood waste. Subsequently transmitted to the metal scrap, wood waste are burned, and the bricks were reused.
In recent years, Republic of Bulgaria create unregulated markets for recycled materials, which is currently not the requisite controls.

Construction and repair activity associated with the formation of large amounts of waste that can be recycled. While the construction and repair of road infrastructure in the Republic of Bulgaria is an activity that incorporates great potential for use of recycled building materials. Unfortunately, the management activities of waste generated by the construction and repair of roads are still only partially covered by the management and control of waste in Republic of Bulgaria. There nebhodimost than just regulating the obligations of contracting authorities and contractors of construction and repair of roads and the establishment of mechanisms to monitor and control the movement and use of waste .

Landfill construction and demolition waste is still the main method of disposal of the construction and demolition waste in the country. At the time and the disposal of these wastes is covered by the following structure:

- 12 pieces municipal construction waste landfills;

- 131 number of landfills;

- 27 number of regional landfills.

Outside these landfills are still in the country has the practice of unregulated disposal of construction and demolition waste unauthorized places, most often located on the outskirts of the settlements.

Factors that influence the size and characteristics of the waste, construction and demolition are different. Unlike household waste, they can not be directly linked to the number of the population. They must be linked to the characteristics of local differences in the renovation of buildings, restructuring of local and outside urban areas, construction and technical aspects of buildings and facilities to be constructed, the buildings are subject to rehabilitation and reconstruction and buildings that will pull down. The dynamics of generating construction and demolition waste than those purely technical factors had an impact and will continue to have the processes of urban development in the country. In this case, they could be arranged as follows: 
- The period of transition caused a crisis in urban development in terms of unfinished public buildings not intended to meet the changed socio-economic conditions;

- Due to the complex social and economic reasons, the development of settlements in the country runs extremely uneven - during the construction boom, for example, the expansion of the construction is realized mainly in and around big cities (Sofia, Plovdiv, Varna, Burgas). It was dictated mainly by the state of the market - demand for residential, office and commercial buildings, but due to lack of regulatory mechanisms lead to a glut in the market. In this period were made and investments without basing itself on a clear vision for the future and as a consequence the wake of an economic crisis, these investments remained unfinished and unsold, ie, it went into operation.

- In view of the persistent demographic trends of population decline can be expected that the new construction will be mainly related primarily qualitative and less quantitative changes;

- Hospitality construction and development, the analysis of which shows excessive construction at sea and mountain resorts and violations of environmental, zoning and construction technical standards, creates potential sources of demolition waste and in the coming years only construction in the balneotherapy tourism can be expected.

As a result of the various analyzes and forecasts based on them the sources of formation of construction and demolition waste can be assumed that the major source of the construction and demolition waste in the next 2020 will be the road sector. This is justified by the fact that the cash that will get Republic of Bulgaria on European programs will be focused mainly on road and rail sector. Given the great opportunities for recycling and recovery of these sectors generated by the construction and demolition waste can be considered that this would be a favorable profile of construction and demolition waste.

To create conditions for effective management was developed Strategic Plan for waste management of construction and demolition waste on the territory of Bulgaria for the period 2011 2020.

National Strategic Plan for waste management of construction and demolition has been developed based on the results of the feasibility study "Preparation of a national strategy for the management of construction waste and demolition." Based on pooled data from different sources and their analysis are made suggestions and expert forecasts are proposed legislative changes and measures to develop infrastructure for 10 years.

Analysis of the current state of the construction and demolition waste and the identification of the problems are the basis on which defined the objectives of the Strategic Plan and related measures in the Action Plan. In it for each of these measures are defined and accountable institutions necessary financial resources to ensure the implementation of the Strategic Plan for the period 2011 - 2020.

In identifying and ranking the measures set out in the National Strategic Plan, the fundamental principles of waste management regulated in the Republic in accordance with the common European and national policies in the field of waste management in construction.

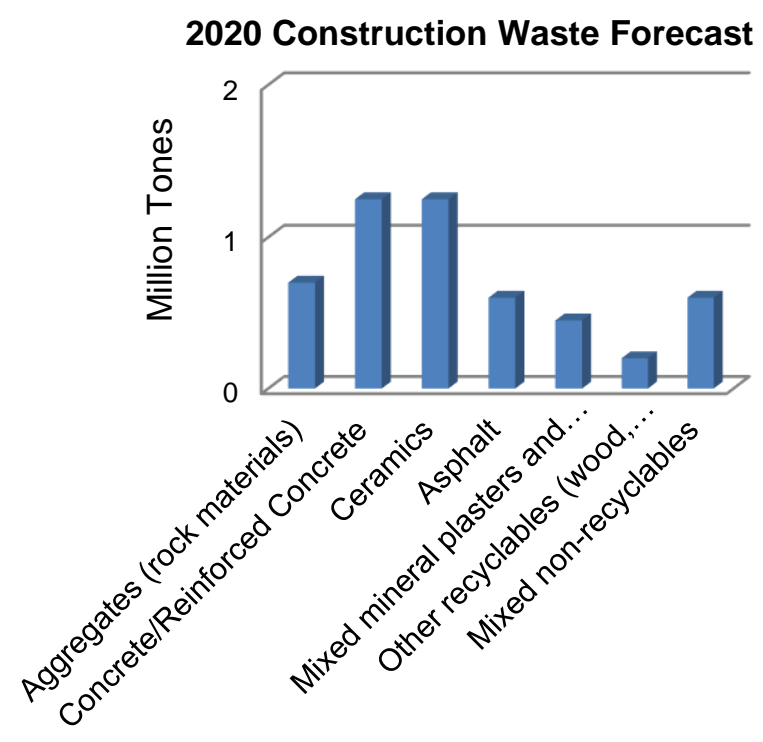

Fig. 1 Construction Waste Forecast Source: (National Strategic Plan, 2011) 
The basic principles underlying the plan are as follows:

- Sustainable development;

- Principle of prevention;

- The principle of self-sufficiency and proximity in waste management;

- hierarchy of waste management;

- Reduce costs by using good technique and technology;

- Responsibilities of pollutants.

As shown in figure 1, based on the developed National Strategic Plan, the expected quantities of different types of construction and demolition waste in 2020 are as follows:

- Aggregates (rock materials) - 700000 tons;

- Concrete / Reinforced Concrete - 1250000 tons;

- Ceramics - 1250000 tons;

- Asphalt -600000 tons;

- Mixed mineral plasters and others - 450000 tons;

- Other recyclables (wood, paper, metal) 200000 tons;

- Mixed non-recyclables -600000 tons

In order to create conditions for effective management and implementation of policy on use of construction waste and use of recycled building materials in the country was the Ordinance on management of construction waste and use of recycled building materials, which entered into force on 13.11.2013, the ordinance aims to create favorable legal and economic conditions for the deployment of technologies to achieve the targets for recovery and recycling of construction waste, according to the financial situation of the companies and the state. The ordinance creating conditions for the production and marketing of materials derived from recycling of construction waste that is commensurate with the quality of the natural raw materials used in construction.

Implementation of the tasks set out in the new regulation will contribute to the sustainable development of Bulgaria as a result of successful waste management of construction and demolition while will reduce the negative environmental impact caused by the construction waste generated, to improve efficiency of resource use, stimulate investment in waste management and to increase the responsibilities of companies and individuals that cause pollution.

The Ordinance complies with the requirements of the Framework Directive 2008/98/EC on waste. It can be considered that the implementation of the requirements of the Regulation will lead to the goal - in 2020 to recycle and recover at least $70 \%$ by weight of construction waste in the country.

The main objective of the normative document is to contribute to sustainable development of the Republic of Bulgaria through an integrated framework for managing waste from construction and demolition to reduce the environmental impacts caused by the construction waste generated, improving the efficiency of resource use, increased responsibilities, and encouraging investment in waste management.

The ordinance provides important requirements:

- Selective deconstruction of buildings with separation of the main components;

- Sorting of waste during the execution of construction and repairs;

- Preparation of operational plans for the management of construction waste;

- Recycling using a variety of modern facilities and use of recycled materials back into production.

The requirements for the preparation of management plans for construction waste will create conditions for ensuring the traceability of the waste from the moment of their formation until they are used as building resource, or possibly their disposal.

The management plan for construction waste should include:

- Data and description of the site of origin of the waste;

- Estimated justification for the type and volume of construction waste generated and the level of material recovery;

- Forecast plan type and quantity of product recovered from construction waste to be invested in this project;

- Measures builder must comply with the implementation, including waste prevention, preparation for re-use, recycling or making 
points to recycling, recovery in backfilling eventually disposal, etc.

In accordance with the Ordinance, contracting of construction works projects financed by public funds, are responsible for the use in the construction of a certain percentage of products derived from the recycling of construction waste. The introduction of this requirement aims to ensure a market for the products of the recycling of construction waste, and encouraging businesses to invest in infrastructure for recycling construction waste. In fact, it can be expected the development of new industrial market for recycling construction waste and their inclusion as components of construction materials. There will also be creating a market for processed construction waste and to regulate and facilitate their reuse in construction.

\section{CONCLUSIONS}

As a result of the implementation of the Regulation can be expected achievement of priority national objectives such as the significant amount of construction waste generated in 2020 , creating favorable conditions for building the necessary infrastructure and provide a market for recycled construction waste and their use in construction or in the manufacture of building products.

Ordinance builds legal regulation in our country, is meeting the European requirements. It regulates the legal management of construction waste, their processing and the development of the market of construction materials derived from recycled materials.

The implementation of the proposed Ordinance will result in the creation of common environmental requirements to reduce pollution of air, water and soil as a result of treatment of construction waste and their management and control in construction and demolition. Will create the conditions for effective management of construction waste, which leads to the construction of environmentally friendly management and control of the collection, transportation and use of recycled construction waste in construction.

Waste management will reduce their harmful effects on human health and the environment.

\section{WORKS CITED}

Ordinance for Management of Construction Waste and Application of Recycled Construction Materials, Council of Ministers Decree 277 on 05.11.2012, promulgated in State Gazette Bulgaria issue 89 on 13.11.2012.

Law on Waste Management, State Gazette Bulgaria issue 53 on 13.07.2012.

Service Contract on Management of Construction and Demolition Waste - SR1. (2011, February). European Commission (DG ENV). Retrieved January 05, 2014, from http://www.eusmr.eu/cdw/docs/BIO_Construction\%20and\%20Demolition\%20Waste_Final\%20report_09022011.pdf

Strategic Plan for Management of Construction and Demolition Waste in the Republic of Bulgaria for 2011-2020, Ministry of Environment and Water, 2011. Retrieved January 05, 2014, from http://www3.moew.government.bg/files/file/Waste/cdw/NSPUOSR-final.pdf

Strategic Plan for Management of Construction and Demolition Waste in the Republic of Bulgaria for 2011-2020, Ministry of Environment and Water, 2011, Appendix 1: Review of the Existing Legislation in the Republic of Bulgaria Related to the Management of Construction and Demolition Waste. Retrieved January 05, 2014, from http://www.moew.government.bg/files/file/Waste/cdw/NSPUOSR-final-ANNEX1.pdf

Strategic Plan for Management of Construction and Demolition Waste in the Republic of Bulgaria for 2011-2020, Ministry of Environment and Water, 2011, Appendix 2: Review of the Legislation on Management of Construction and Demolition Waste (CDW) in EU Member States and Description of European Best Practices. Retrieved on January 05, 2014, from http://www.moew.government.bg/files/file/Waste/cdw/NSPUOSR-final-ANNEX2.pdf

Strategic Plan for Management of Construction and Demolition Waste in the Republic of Bulgaria for 2011-2020, Ministry of Environment and Water, 2011, Appendix 3: Technical Description of the Various Scenarios for Developing a System for Treatment of Construction and Demolition Waste in Bulgaria (Assessment and comparison of the various types of systems for separate collection, reuse, recycling and recovery 
of CDW in the public and private sector). Retrieved January 05, 2014, from http://www.moew.government.bg/files/file/Waste/cdw/NSPUOSR-final-ANNEX3.pdf

Zahariva R. (2013, May). Construction Waste as a Resource: Application of Ordinance for Construction Waste from Municipalities. Retrieved January 05, 2014, from http://new.sliven.net/res/news/110104/Presentation-ACEKOBv2.pdf

Received for publication: $\quad 01.04 .2014$

Revision received: $\quad 27.12 .2014$

Accepted for publication: $\quad 11.05 .2015$

\section{How to cite this article?}

Style - APA Sixth Edition:

Tasov, K., \& Stoyanov, V. (2015, July 15). Status and practices for managing construction waste in the Republic of Bulgaria. (Z. Čekerevac, Ed.) MEST Journal, 3(2), 110-117. doi:10.12709/mest.03.03.02.12

Style - Chicago Sixteenth Edition:

Tasov, Konstantin, and Ventsislav Stoyanov. 2015. "Status and practices for managing construction waste in the Republic of Bulgaria." Edited by Zoran Čekerevac. MEST Journal (MESTE) 3 (2): 110-117. doi:10.12709/mest.03.03.02.12.

Style - GOST Name Sort:

Tasov Konstantin and Stoyanov Ventsislav Status and practices for managing construction waste in the Republic of Bulgaria [Journal] // MEST Journal / ed. Čekerevac Zoran. - Belgrade : MESTE, July 15, 2015. - 2 : Vol. 3. - pp. 110-117.

Style - Harvard Anglia:

Tasov, K. \& Stoyanov, V., 2015. Status and practices for managing construction waste in the Republic of Bulgaria. MEST Journal, 15 July, 3(2), pp. 110-117.

Style - ISO 690 Numerical Reference:

Status and practices for managing construction waste in the Republic of Bulgaria. Tasov, Konstantin and Stoyanov, Ventsislav. [ed.] Zoran Čekerevac. 2, Belgrade : MESTE, July 15, 2015, MEST Journal, Vol. 3, pp. 110-117. 